\title{
Intracellular Deoxyribonucleic Acid-modifying Activity of Phototherapy Lights
}

\author{
WILLIAM T. SPECK ${ }^{14}$ AND HERBERT S. ROSENKRANZ \\ Department of Pediatrics and Microbiology, College of Physicians and Surgeons, Columbia University, \\ New York, New York, USA
}

Extract

Little information is available on the intracellular consequences of the high intensity illumination with visible light that is commonly used in the treatment of neonatal hyperbilirubinemia. The present study was undertaken to determine whether DNA isolated from human cells growing in culture had undergone structural alterations as a result of exposure to high intensity visible light in the absence of added photosensitizers. Analysis of such DNA on alkaline sucrose gradients revealed a diminution in size after illumination. This structural lesion was repairable when the treated cells were subsequently incubated in the dark. These changes were observed at wave lengths $(450 \mathrm{~nm})$ of light identical with those utilized in phototherapy and with total light doses $\left(70.4 \mathrm{~kJ} / \mathrm{m}^{2}\right)$ representing only $5 \%$ of that received by a newborn infant undergoing phototherapy in our nursery for a $24-\mathrm{hr}$ period $\left(1.3 \times 10^{3} \mathrm{~kJ} / \mathrm{m}^{2}\right)$.

\section{Speculation}

In view of the known relationship between DNA-modifying activity and mutagenic and/or carcinogenic potential, the present results suggest that phototherapy is a complex process with an inherent potential for serious long term sequelae.

Recently an environmental agent unique to the newborn infant-high intensity illumination with visible light or phototherapy-was introduced into the practice of pediatrics. The effectiveness of this agent in reducing serum bilirubin concentrations in jaundiced infants is so well established and its usage so widespread that there is some concern about its overuse, particuarly in circumstances where it may be neither necessary nor beneficial (1). This concern is heightened by a lack of information on all of the biochemical processes involved in the in vivo photodecomposition of bilirubin. An additional cause for concern is the presence in vivo of photo-oxidizable substances other than bilirubin (e.g., certain amino acids, vitamins, and pigments) which are photoactivated by wave lengths of light identical with those utilized in phototherapy. The effect of these photochemical reactions on child health is a matter of speculation. Because of such considerations our laboratory has undertaken a systematic study of the potential genetic consequences of phototherapy. We have demonstrated previously that visible light $(450 \mathrm{~nm})$ is able to induce genetic changes in prokaryotic (5) and eukaryotic (7) cells and that illumination of isolated DNA in the presence of bilirubin and/or riboflavin $(4,6,7)$ resulted in alterations in the physical and chemical properties of this biopolymer. The present report demonstrates structural changes in the DNA isolated from human cells growing in culture after exposure to high intensity illumination in the absence of added photosensitizers.

\section{MATERIALS AND METHODS}

\section{CULTURED CELLS}

Suspensions of human (KB) cells growing in Eagle's medium containing glutamine and calf serum $(10 \%)$ were supplemented with $\left[{ }^{3} \mathrm{H}\right]$ thymidine $(6 \mathrm{Ci} / \mathrm{mmol})$ such that the final concentration was $8.3 \mu \mathrm{ci} / \mathrm{ml}$. Five-milliliter portions of these suspensions were distributed into $30-\mathrm{ml}$ plastic tissue culture flasks. The flasks were incubated for $18 \mathrm{hr}$, by which time monolayers of cells had formed on the surface of the plastic. The supernatant culture fluids were decanted and replaced with fresh, nonradioactive medium. The cells were incubated for an additional $24 \mathrm{hr}$, whereupon the medium was discarded and the cells were washed four times with 5 -ml portions of dextrose in saline $(5 \%$ dextrose in $0.15 \mathrm{M} \mathrm{NaCl})$. Five-milliliter portions of dextorse in saline were added to each flask and the cells were either illuminated or kept in the dark. After this procedure cells were either processed for DNA isolation or they were reincubated in complete medium to stimulate DNA repair.

\section{ILLUMINATION}

Phototherapy units either with white light (Dura-Test Vita Lite) or Special High Energy Blue Westinghouse bulbs (F20T12-BB), which have a peak emission at $450 \mathrm{~nm}$, were used to provide illumination. The units were protected from direct sunlight and air-cooled to maintain the cells at $23^{\circ}$. The distance between the cells and light sources was adjusted to maintain a fluence rate (at $450 \mathrm{~nm}$ ) of 141 and $652 \mu \mathrm{W} / \mathrm{cm}^{2}$ for the white and blue lights, respectively. Photometric measurements were made with an IL600A photometer coupled to an IL600 photodensitometer manufactured by International Light, Inc. (6).

\section{DNA ISOLATION}

After the various procedures, the cell layers were washed with phosphate-buffered salinc (PBS), removed from the plastic layer by scrapping, and resuspended in $1 \mathrm{ml}$ PBS; $\mathrm{Na}_{2}$ EDTA and sodium lauryl sulfate were added to final concentrations of 0.4 $\mathrm{mg} / \mathrm{ml}$ and $2 \%$, respectively; an equal volume of phosphate-buffered phenol was added; and the suspension was shaken 10 times gently by inversion. The aqueous phase was removed and stored at $-20^{\circ}$. This material was stable for prolonged periods of time.

\section{SUCROSE GRADIENT CENTRIFUGATION}

Dilutions of material present in the aqueous phase in $0.1-\mathrm{ml}$ volumes were layered on top of $4.5 \mathrm{ml}$ of a $5-20 \%$ sucrose gradient in $0.1 \mathrm{M} \mathrm{NaOH}$ containing, at the bottom, a cushion of $50 \%$ alkaline sucrose. The samples were spun in the SW50.1 rotor at $30,000 \mathrm{rpm}$ at $23^{\circ}$ for $2.5 \mathrm{hr}$, whereupon fractions were collected for determination of radioactivity. 


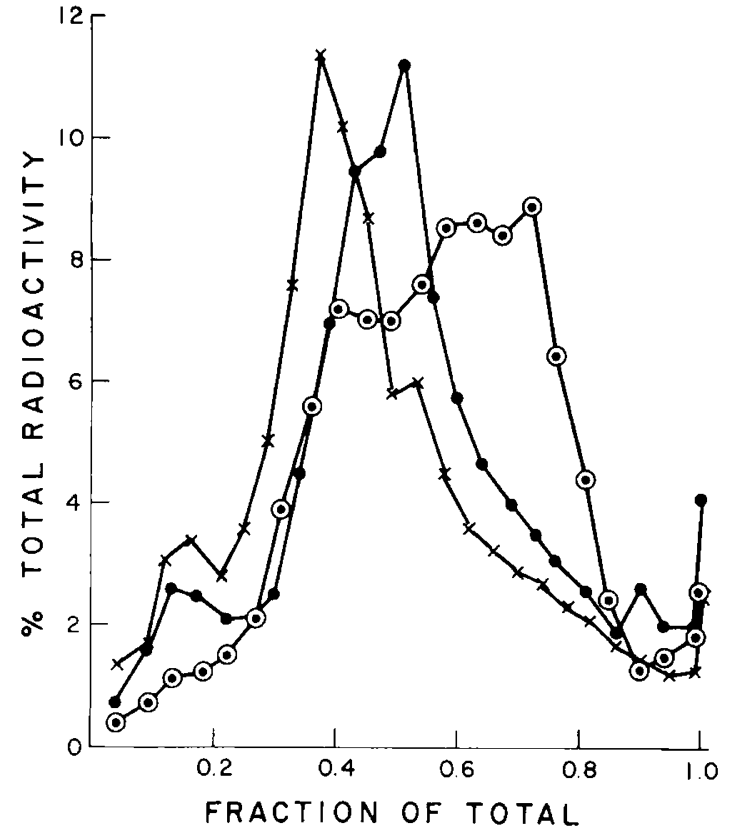

Fig. 1. Effect of illumination with blue light on the centrifugal behavior of DNA isolated from KB cells. (X: control (cells kept in dark); $\odot$ : DNA from cells exposed to blue light; : DNA from cells exposed to blue light and subsequently incubated in the dark $(2 \mathrm{hr})$ to allow DNA repair. The direction of sedimentation is from right to left. (The bottom of the gradient is at the left).

\section{RESULTS}

Exposure of $\mathrm{KB}$ cells to blue light $\left(70.4 \mathrm{~kJ} / \mathrm{m}^{2}\right)$ resulted in a degradation of the cellular DNA as determined by centrifugations in gradients of alkaline sucrose (Fig. 1). The extent of the breakdown varied from experiment to experiment even when the dosage of light was kept constant. It was ascertained that this effect was not due to a photosensitizing effect of any residual phenol red originally present in the medium, as this substance is not photoactivated by blue light $(450 \mathrm{~nm})$. If, after illumination, the cells were placed once more in complete medium and incubated in the dark, evidence of DNA repiar was obtained (Fig. I). In some experiments the sedimentation behavior of the DNA of such repaired cells was indistinguishable from DNA derived from untreated cells.

Evidence of modification of the cellular DNA was also obtained upon illumination of $\mathrm{KB}$ cells with white light $\left(15.2 \mathrm{~kJ} / \mathrm{m}^{2}\right.$ measured at $450 \mathrm{~nm}$ ). In this instance, again, DNA repair was evident when treated cells were incubated in the dark (Fig. 2).

\section{DISCUSSION}

The observation that visible light in the absence of added photosensitizers is capable of causing an alteration of the DNA of human cells growing in culture has not been reported previously (9). Moreover, the repairability of the lesion indicates that the degradation of the DNA is specific and does not reflect a general toxic effect of illumination on the cells resulting in autolysis. The exact nature of this new photochemical reaction remains to be elucidated; however, we have shown that it occurs at wave lengths of visible light considered by many to be optimal for phototherapy, i.e., $450 \mathrm{~nm}(2,3)$, and that the dosage of light necessary for DNA photodegradation represents only a fraction of that received by a newborn infant in our nursery over a 24 -hr period of phototherapy $\left(1.3 \times 10^{3} \mathrm{~kJ} / \mathrm{m}^{2}\right)$.

Our previous findings showed that neither of the light sources used in this study had an effect on the structure of isolated DNA in the absence of added photosensitizers $(4,6)$. The present results, when considered together with our earlier findings, i.e. $(l)$ visible

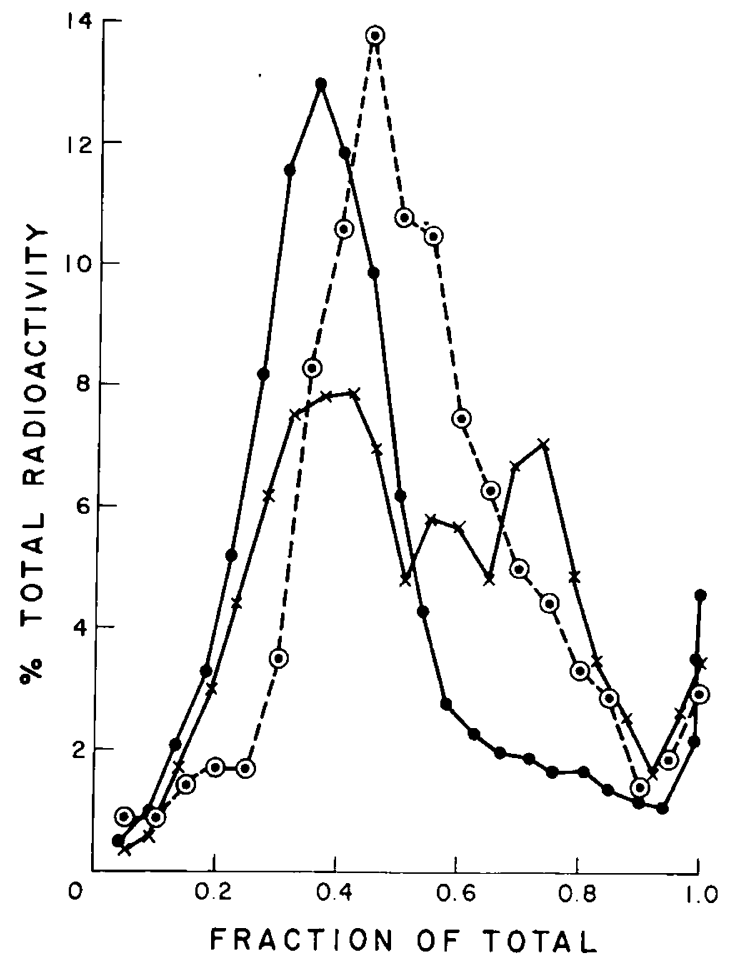

Fig. 2. Effect of illumination with white light on the centrifugal behavior of DNA isolated from KB cells. DNA from cells kept in the dark; $\mathrm{X}$ : DNA from cells exposed to white light; $\odot$ : DNA from cells exposed to white light and subsequently incubated in the dark $(2 \mathrm{hr})$ to allow DNA repair. (The bottom and top of the gradient are to the left and right, respectively.)

light $(450 \mathrm{~nm})$ had a genetic effect on eukaryotic (yeast) and prokaryotic cells $(5,7)$, and (2) illumination of DNA in the presence of physiologic levels of riboflavin, a vitamin ubiquitous to most living cells, resulted in altered physical chemical properties of this macromolecule (4), raises the possibility that the intracellular chromophore excited by visible light $(450 \mathrm{~nm})$ and which precipitates the photodegradation of DNA is riboflavin, a substance which has a peak absorption at $450 \mathrm{~nm}$. We suspect from our earlier observations (4) that this depolymerization is due, in part, to the selective destruction of the guanine moiety of DNA. Studies are in progress to test this hypothesis.

These results which demonstrate that a commonly utilized therapeutic maneuver possesses DNA-modifying activity are somewhat disconcerting when it is realized that mutagens as well as chemical carcinogens derive their activity, in part, from their ability to react with and modify intracellular DNA. Our studies continue to indicate that high intensity illumination of newborn infants with visible light for extended periods may not be a totally innocuous procedure.

\section{SUMMARY}

Human cells growing in tissue culture were exposed to phototherapy lights. DNA isolated from these cells had lower molecular weights than that derived from cells kept in the dark. These lesions in the genetic material were repairable when the irradiated cells were subsequently incubated in the dark. The dosage of light required to demonstrate these effects was only a fraction of that received by a newborn infant undergoing phototherapy in our nursery for a 24 -hr period.

\section{REFERENCES AND NOTES}

1. Behrman, R. E., Brown, A. I., Currie, M. R., Hastings, J. W., Odell, G. B. Schaffer, R., Setlow, R. B., Vogl, T. P., Wurtman, F. J., Anderson, R. J. 
Kostkowski, H. J and Simpoulos, A. P.: Preliminary report of the committee on phototherapy in the newborn infant. J. Pediat., 84: 135 (1974).

2 Broughton $P, M, G$. The effectiveness and safety of phototherapy. In: D. Bergsma, D. Y Y Hsia, and C. Jackson: Bilirubin Metabolism in the Newborn, Vol. 6, No. 2, p. 71. Birth Defects: Original Articles Series, 1970.

3. Sisson, T. R. C., Kinda!!, N., Davies, R. E., and Berger, D.: In: D. Bergsma, D Y. Y. Hsia, and C. Jackson: Bilirubin Metabolism in the Newborn, Vol. 6, No. 2, p. 100. Birth Defects: Original Articles Series, 1970.

4. Speck, W. T. Chen, C. C., and Rosenkranz, H. S. In vitro studies of the effects of light and riboflavin on DNA and HeLa cells. Pediat. Res., 9: 150 (1975).

5. Speck, W. T., and Rosenkranz, H.S.: Base substitution mutations induced in Salmonella strains by visible light $(450 \mathrm{~nm})$. Photochem. Photobiol., 21: 369 (1975).

6. Speck, W. T., and Rosenkranz, H. S.: The bilirubin-induced photodegradation of DNA. Pediat. Res., 9: 703 (1975)

7. Speck, W. T., and Rosenkranz, H. S.: Unpbulished results.

8. Newburyport, Mass.

Copyright $(c) 1976$ International Pediatric Research Foundation, Inc.
9. In a previous study (Reference 4) we reported that HeLa cells exposed to light in the presence but not the absence of riboflavin exhibited decreased molecular weights. This lack of effect of light in the absence of added photosensitizer appears to be due to a lower dose of light at $450 \mathrm{~nm}$ and to a differen susceptibility of HeLa cells.

10. We are indebted to $\mathrm{Mr}$. Howard $\mathrm{S}$. Carr without whose devoted help these experiments could not have been performed.

11. William T. Speck is The Vivian Allen Fellow in Clinical Medicine.

12. Herbert $S$. Rosenkranz is a Research Career Development Awardee of the National Institute of General Medical Sciences (5 K3-GM 29, 024).

13. This research was supported by a gift from the George D. Smith Fund, Inc., and by the Division of Cancer Cause and Prevention, National Cancer Institute (NOI-CP-33395).

14. Requests for reprints should be addressed to: W. T. Speck, M.D., Department of Pediatrics, College of Physicians and Surgeons, Columbia University, 630 West 168th St., New York, N. Y. 10032 (USA).

15. Accepted for publication November 17, 1975. 